Dhaka Univ. J. Biol. Sci. 20(1): 7-13, 2011 (January)

\title{
VERTICAL DISTRIBUTION OF PHYTOPLANKTON IN A HYPERTROPHIC JHEEL, MIRPUR, DHAKA
}

\author{
Moniruzzaman KhondKer ${ }^{1}$, Md. Shafiqul Islam ${ }^{2}$ and Humayra Afroze ${ }^{3}$ \\ Department of Botany, University of Dhaka, Dhaka-1000, Bangladesh
}

Key words: Vertical distribution, Phytoplankton, Hypertrophic Jheel

\begin{abstract}
Four species of phytoplankton namely, Arthrospira platensis, Phacus ranula, Oscillatoria chalybea, and Euglena variabilis showed vertical depth distribution in different seasons. A. platensis and O. chalybea were found to co-exist and showed almost identical seasonal depth distribution pattern. $P$. ranula preferred to grow in the illuminated upper zone of the water body while E. variabilis showed moderate growth also at the bottom where the concentration of soluble reactive phosphorus was very high $(506-1554 \mu \mathrm{g} / \mathrm{l})$. A. platensis and O. chalybea grew luxuriantly in summer and monsoon seasons while $P$. ranula and $E$. variabilis were abundant in winter.
\end{abstract}

\section{Introduction}

Besides annual, seasonal and diel distribution, phytoplankton also show their different scales of density along water depth. This is usually associated with temporal changes in mean temperature, irradiance, hydraulic throughput and nutrient availability of a water column. These could be non-motile negatively buoyant, positively buoyant and neutrally buoyant phytoplankton. ${ }^{(1)}$ Interactions occurring between organisms and water layers particularly with the motile cryptomonads have been studied in temperature waters. $(2,3)$ Competitive exclusion and climatic dominance among phytoplankton population may be prevented because of the morphometry, seasonal variability and physical stochasticity of many water bodies.(4)

In Bangladesh, though a significant number of studies have been carried out on the seasonality of phytoplankton, there exists a few on vertical distribution. ${ }^{(5-8)}$ Considering the humid climate of Bangladesh together with a relatively shallow basin formation in most of the water bodies the present investigation was undertaken to find the vertical periodicity of some dominant phytoplankton in a Jheel (large pond). The Jheel was found to be an eutrophicated water body with a heavy load of bacterial suspension. $(9,10)$

${ }^{1}$ Corresponding author. ${ }^{2}$ Ansar Academy, Shafipur, Gazipur, Bangladesh. ${ }^{3}$ Scott \& White Memorial Hospital, 702 SW HK Dodgen Loop, Medical Research Building, West Loading Dock, Temple, TX, 76508, USA. 


\section{Materials and Methods}

The water body is located at the Section 7, Mirpur, Dhaka having an area of 3 ha and a maximum water depth of $4.69 \mathrm{~m}$. It is perennial and L-shaped (Fig. 1). Water samples for the determination of limnological water quality and plankton analyses were collected from 0.5, $2.0 \mathrm{~m}$ and from the bottom (varied between 3.2 and $4.69 \mathrm{~m}$ ) with the help of a Schindler's Sampler (5 L cap.). Details of the methodology regarding the other limnological factors were furnished in Afroze and Khondker.(9) For the qualitative and quantitative analysis of phytoplankton, a concentrated sample from each of the above mentioned depths were obtained via sedimentation process with Lugol's iodine. A definite volume of sub-sample was counted under a Nikon compound microscope with a magnification of $\times 200$ using a Sedgeweck Rafter Counting Cell (Graticules Ltd., U.K.). However, to identify the species higher magnifications $(400-1000 \times)$ were used.

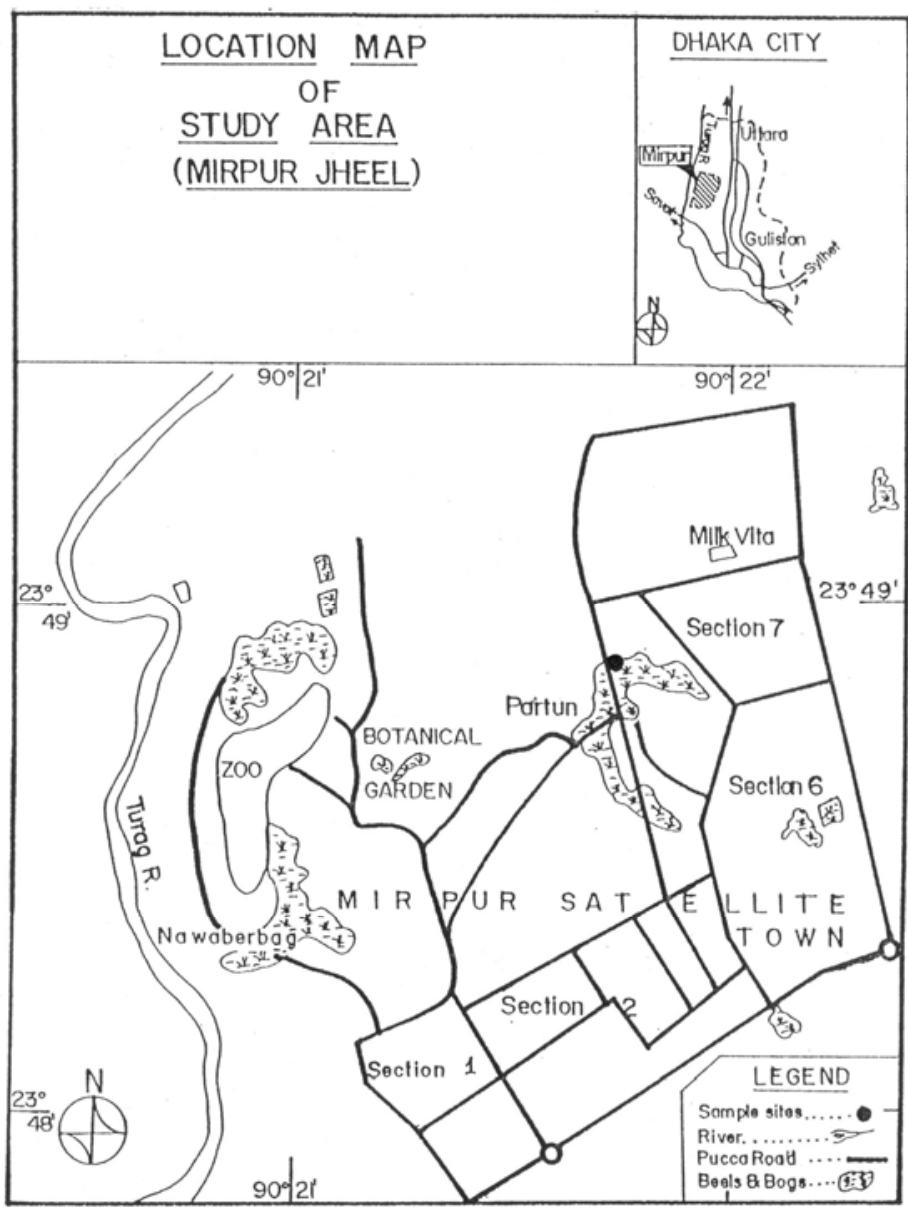

Fig. 1. Showing the study site of hypertrophic Jheel, Mirpur, Section 7, Dhaka metropolis. 


\section{Results and Discussion}

The data on water quality parameters collected over the period of investigation are pulled together with seasonal means and shown in Table 1. Among these parameters, the maximum water depth of the Jheel was found to fluctuate within $4.0-4.5 \mathrm{~m}$ in different seasons being the highest depth in monsoon to autumn and lowest in summer.

Consequently, the Secchi visibility was within $15-27 \mathrm{~cm}$ with the highest in autumn and lowest in summer (Fig. 2).

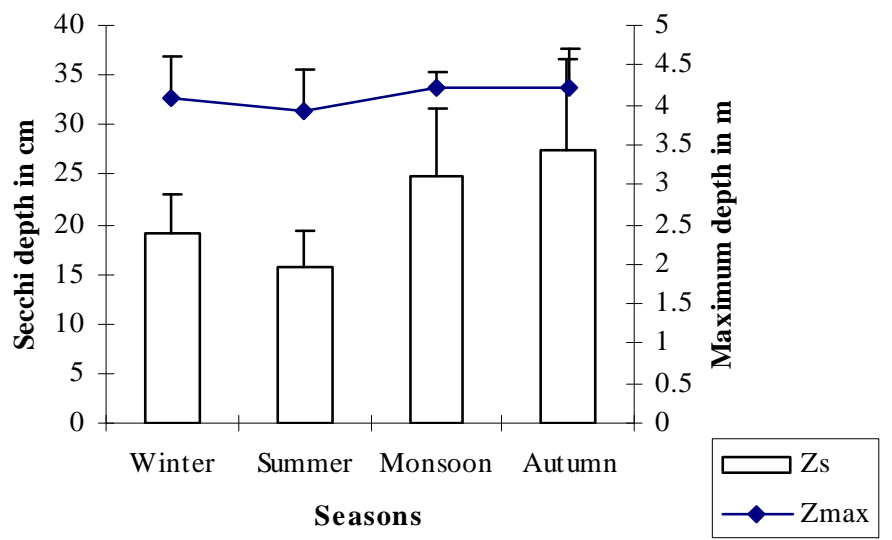

Fig. 2. Showing the mean seasonal values of maximum water depth (Zmax) and Secchi depth (Zs).

Compared to the temperature of top most water column, the bottom water temperature in different seasons differed by $0.8,3.4,1.5,1.0^{\circ} \mathrm{C}$ in winter, summer, monsoon and autumn, respectively (Table 1). So, the maximum difference was found in summer. Penetration of photosynthetically active radiation (PAR) in different depth of water also changed with seasons, such as, it was up to $200 \mathrm{~cm}$ in monsoon and autumn but, not in other two seasons (Table 1). No significant change in the $\mathrm{pH}$ value in different depths of water was observed, however, the trend showed slight reduction with the increasing depth of water. These changes included the maximum 8.0 in autumn at the upper part and minimum 6.6 in monsoon at the bottom part of the Jheel water. The parameter, water conductivity was highest $643.3 \mu \mathrm{S} / \mathrm{cm}$ in summer at the bottom water and against that of the lowest $374.0 \mu \mathrm{S} / \mathrm{cm}$ at $50 \mathrm{~cm}$ depth of water. Unless, the water laying with $200 \mathrm{~cm}$ depth was always medium in conductivity value. Similarly, the alkalinity concentration of bottom water was little higher i.e., 5.9, 3.8 and $3.5 \mathrm{meq} / \mathrm{l}$ in summer, monsoon and autumn, respectively than the other depth of water (Table 1).

Dissolved oxygen (DO) was detectable only in the top most water column $(50 \mathrm{~cm})$. In other depths, it did not fall within the detection limit. Even, the concentration of DO showed different values in different seasons. In winter, it was $1.4 \mathrm{mg} / \mathrm{l}$ which improved 


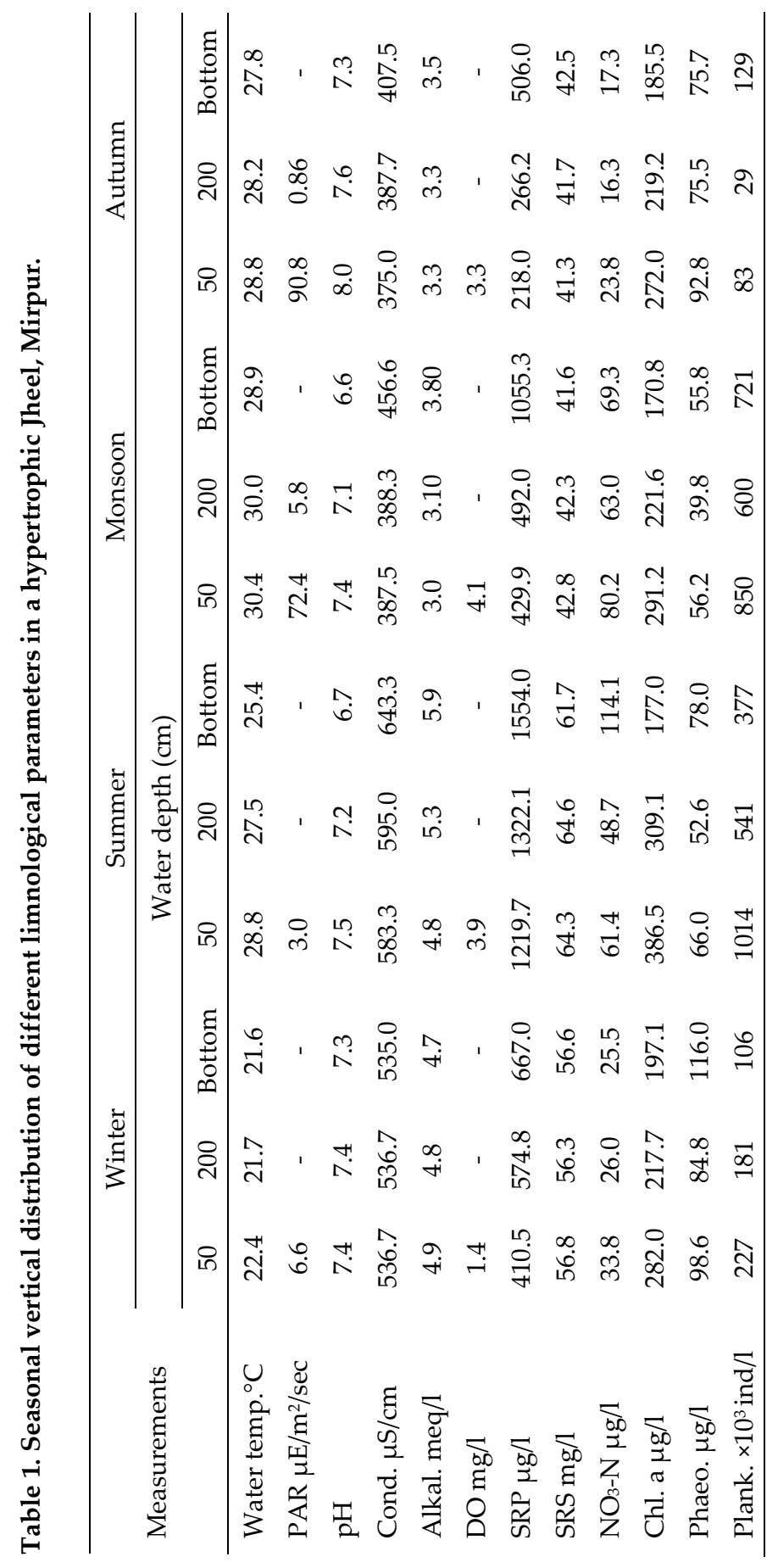


in monsoon $(4.1 \mathrm{mg} / \mathrm{l})$ via summer $(3.9 \mathrm{mg} / \mathrm{l})$. In autumn, it fell again $(3.3 \mathrm{mg} / \mathrm{l})$. In all the seasons bottom water contained a very high concentration of soluble reactive phosphorus (SRP). Highest value $1554 \mu \mathrm{g} / \mathrm{l}$ was obtained in the bottom water of summer. This increasing trend followed from winter to summer and then a fall from monsoon to autumn (Table 1). Soluble reactive silicate (SRS) ranged from 41.3-64.6 mg/l and showed no significant variation along the depth gradient. Except summer, the $\mathrm{NO}_{3}-$ $\mathrm{N}$ contents of bottom water were always lower than surface water. The chlorophyll-a concentration was low in the bottom water in all the seasons. It did correspond with the total plankton density at least in winter, summer and monsoon. However, the cell density did increase in autumn. The concentration of phaeopigment was always lower in the bottom waters throughout the seasons (Table 1).

A total of nine species belonging to the genera Euglena, Trachelomonas, Phacus and Microcystis were found to occur within the counting range (at least 100 counted cells). In these, four species showed some sorts of vertical distribution which has been plotted in Fig. 3. The species Arthrospira platensis (Nordst.) Gom., Phacus ranula Pochm., Euglena variabilis Klebs and Oscillatoria chalybea (Mertens) Gom. showed vertical distribution in different seasons. A. platensis dominated the community in summer and monsoon seasons. In summer, the species showed its highest density in $50 \mathrm{~cm}$ water depth and then gradually depleted through $200 \mathrm{~cm}$ to bottom and regain its uniform distribution, throughout the depth (Fig. 3). Another member of the blue-green algae O. chalybea also showed the same tendency as that of A. platensis along the depth gradient (Fig. 3). Among the two other euglenoids, $P$. ranula was present in the community in all the seasons (Fig. 3). In winter, its population was recorded in all the depth profile of the water body, but its highest number was recorded in the $50 \mathrm{~cm}$ water depth which depleted gradually in two other depths, namely $200 \mathrm{~cm}$ and bottom. In summer, the total population of $P$. ranula occurred only in $50 \mathrm{~cm}$ water depth while in monsoon they occurred in both 50 and $200 \mathrm{~cm}$ water depth. Population of this species occurred in autumn season only in $50 \mathrm{~cm}$ depth (Fig. 3). E. variabilis grew in winter summer and autumn. In monsoon, it was absent from the community. In winter, E. variabilis was present in all the three depths showing its highest density in $50 \mathrm{~cm}$. At $200 \mathrm{~cm}$, its population was low compared to bottom water (Fig. 3). In summer and autumn, the species showed its presence only in the $50 \mathrm{~cm}$ water depth.

In a mesotrophic pond of Dhaka Khondker and Chowdhury(6), showed a continuous presence of Cryptomonas ovata Ehrenberg and Scenedesmus armatus Chod. at $50 \mathrm{~cm}, 250 \mathrm{~cm}$ and in the bottom all through the year. Light penetration in that pond was satisfactory, i.e., PAR was detectable up till bottom. However, in the present study PAR was always detectable up to $50 \mathrm{~cm}$ depth of water but, only in the monsoon and autumn it can reach up to $200 \mathrm{~cm}$. However, throughout the study, no record obtained about the penetration of PAR up to bottom (Table 1). Regarding nutrient concentration the present Jheel is 
hypertrophic i.e., with abundant phosphorus and nitrogen (Table 1). So, A. platensis, $O$. chalybea, E. variabilis and P. ranula favour to grow in low light but nutrient enriched habitats. Reynolds( ${ }^{(4)}$ stated that the genera of some euglenophytes are commonly associated with organically-rich habitats. The occurrence of both $O$. chalybea and $A$. platensis in summer and monsoon and almost in similar depth gradients strongly suggest

Oscillatoria chalybea (Mertens) Gom.

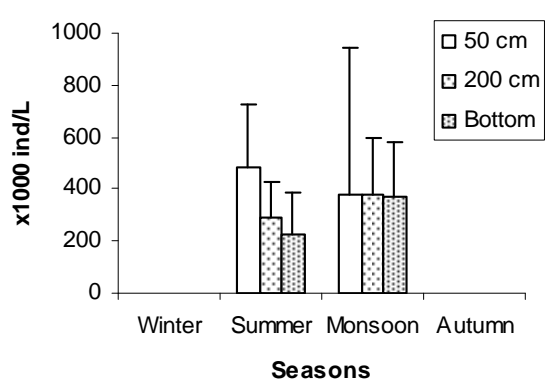

Arthrospira platensis (Nordst.) Gom.

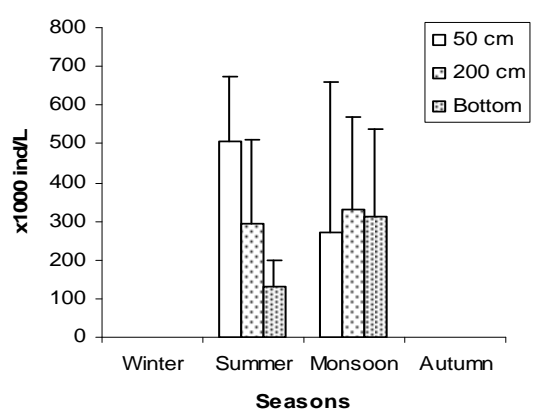

Euglena variabilis Klebs
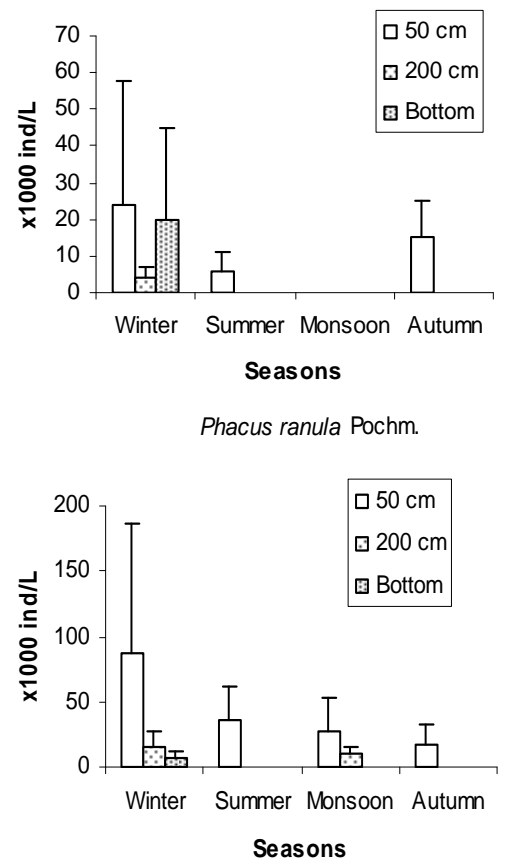

Fig. 3. Seasonal vertical distribution of dominant phytoplankton in hypertrophic Jheel, Mirpur.

that this two species are coexisting with each other (Fig. 3). P. ranula showed a very clear decreasing trend in its density from winter to autumn (Fig. 2). Though this pattern was not evident in the distribution of $E$. variabilis but yet both the euglenoids showed their prevalence in the illuminated zone of the water body (Fig. 3). Mainly light controlled distribution of cryptomonads has been observed in Lake Constance by Sommer.(2) Reynolds $^{(4)}$ stated that filamentous blue-greens, such as Oscillatoria and Lyngbya are potentially stratifying species and widespread in occurrence. Because of their chromatic adaptation phenomenon, they may grow up to certain depths in water body. Reynolds ${ }^{(4)}$ showed the occurrence of highest density of Lyngbya sp. and Microcystis spp. at $6 \mathrm{~m}$ depth and $16-20 \mathrm{~m}$ depths, respectively. 


\section{References}

1. Reynolds CS 1984. The ecology of freshwater phytoplankton. Cambridge Univ. Press, Cambridge, U.K. pp. 384.

2. Sommer U 1985a. Differential migration of Cryptophyceae in lake Constance. In: M.A. Rankin, ed. Migration: Mechanism and adaptive significance. Univ. of Texas Symp. p. 166-175.

3. Sommer U 1985b. Seasonal Succession of phytoplankton in Lake Constance. Bio. Science 35(6): 351-357.

4. Reynolds CS 1997. On the vertical distribution of phytoplankton in the Middle Rio Doce Vale Lakes. In: JG Tundisis and Y Sijo, eds Limnological Studies on the Rio Doce Valley Lakes, Brazil. p. 227-241.

5. Khondker M and L Parveen 1992. Species composition, standing crop and seasonality of phytoplankton in a hypertrophic lake. Dhaka Univ. Stud. Pt. E, 7(1): 49-55.

6. Khondker M and SA Chowdhury 1993a. Relationships of phytoplankton biomass to some water quality parameters in a mesotrophic pond. Dhaka Univ. J. Biol. Sci. 2(1): 87-92.

7. Khondker M and SA Chowdhury 1993b. Vertical distribution and periodicity of pelagic phytoplankton in a pond. J. Asiat. Soc. Bangladesh Sci. 19(1): 9-13.

8. Sultana M, M Khondker and A Aziz 1999. Plankton composition and its seasonal dynamics in two urban ponds. Dhaka Univ. J. Biol. Sci. 8(1): 35-43.

9. Afroze SH and M Khondker 1995. On eutrophication of small waterbody: a case study in Bangladesh. Bangladesh J. Bot. 24(2): 213-215.

10. Afroze SH and M Khondker 1996. Status of coliform bacteria and heavy metal concentration in a eutrophicated waterbody. Dhaka Univ. J. Biol. Sci. 5(1): 109-112.

(Manuscript received on 22 April, 2010; revised on 13 March, 2010) 